Original scientific paper - Izvorni znanstveni rad

UDK: 637.146 .21

\title{
Rheological, texture and sensory properties of kefir from mare's milk and its mixtures with goat and sheep milk
}

\author{
Dorota Cais-Sokolińska ${ }^{1}$ Jacek Wójtowski ${ }^{*}, J_{\text {an Pikul }}^{1}$ \\ ${ }^{1}$ Department of Dairy Technology, Faculty of Food Science and Nutrition, \\ Poznań University of Life Sciences, 60-624 Poznań, Poland \\ ${ }^{2}$ Department of Animal Breeding and Product Quality Assessment, \\ Faculty of Veterinary Medicine and Animal Science, \\ Poznań University of Life Sciences, 62-002 Suchy Las, Poland
}

Received - Prispjelo: 25.02.2016. Accepted - Prihvaćeno : 20.10.2016.

\begin{abstract}
The aim of this study was to conduct lactic acid-alcoholic fermentation using mesophilic lactic acid bacteria (LAB) for mare's milk and its mixture with goat and sheep milk, followed by instrumental and sensory characteristic of the texture profile in the produced kefirs. It was shown that kefirs made from a mixture of goat and sheep milk are firmer, have greater values of consistency and the viscosity index than those produced from mare's milk alone. Kefir storage for 3 weeks causes changes in their mechanical properties. Exceptions are found for firmness of kefirs made from both mixtures and the viscosity index of kefir made from sheep milk, which remained stable. The most divergent texture profile of the tested kefirs was reflected in the sensory examined descriptors of prickling, dense and mouth-coating sensation.
\end{abstract}

Key words: mares, goat, sheep, milk, kefir

\section{Introduction}

Modern consumers are constantly increasing their requirements modern related to dairy products. On the one hand, they concern quality, attractiveness and packaging of milk products (Singh et al., 2012). On the other hand, they are connected with functional characteristics, contents of bioactive compounds, as well as new sensory attributes (Cais-Sokolińska et al., 2015a). The willingness of producers to meet these expectations is a driving force for innovations in the dairy industry. These consist in the modification of the raw material composition of dairy products, combinations of various raw materials, introduction of novel technologies or improving those already applied on the commercial scale (Arora et al., 2015; Cais-Sokolińska et al., 2015b). Examples reported in literature on the subject concerning combining milk of different mammals in one product in the industrial practice also result from economic considerations and seasonal availability of the raw materials (Kücúkcetin et al., 2003; Uysal et al., 2003; Wójtowski et al., 2003; Cagno et al., 2004; Stelios and Emmanuel, 2004; Vargas et al., 2008).

One of the examples of innovations in the dairy industry is related to the use of mare's milk which is usually not collected on a large scale and as such it is not commercially processed (Pikul et al., 2008). For this reason it may be an excellent supplement for other types of milk, particularly as it contains many bioactive components, such as lactoferrin, lysozyme, valuable whey proteins, etc. Contents of selected bioactive components in mare's milk are much greater than in milk of other mammalian 
species (Markiewicz-Kęszycka et al., 2013). Such mixtures typically include milk of small ruminants, i.e. sheep and goats, in contrast to mare's milk containing large amounts of the so-called rumenic acid (conjugated linoleic acid, CLA), a particularly valuable, polyunsaturated fatty acid (Wójtowski et al., 2003; Cabiddu et al., 2005; Decandia et al., 2007; Ceballos et al., 2009). Conjugated isomers of linoleic acid (CLA) are ascribed e.g. a reduction of both the level of low-molecular lipoproteins (LDL) and the ratio of low- and high-molecular lipoproteins, thus decreasing the risk of atherosclerosis (Sieber et al., 2004).

When designing the composition of milk mixture of different mammalian species it is also necessary to consider the technology of its further processing. It is attempted not only to retain the bioactive compounds contained in the components used in production, but also to enhance the healthpromoting value of the final product. Production of fermented milk is such a technology. In the opinion of consumers mare's milk is most frequently associated with a fermented product, kumis (Nassal and Rembalski, 1980; Kücűkcetin et al., 2003; Cagno et al., 2004; Bornaz et al., 2010). However, an equally valuable product may be obtained by lactic acid-alcoholic fermentation, in which thermophilic lactic acid bacteria (LAB) are replaced with mesophilic LAB.

Most literature data on rheology of fermented milks concern the counts and type of acidifying microflora (Shihata and Shah, 2002) as well as application of various thickeners and/or stabilizing agents (Sandoval-Castilla et al., 2004). However, there are only few studies concerning mechanical properties of fermented mare's milk, particularly its mixtures containing milk of ruminants. In the present study it was hypothesized that kefirs produced from a mixture of goat or sheep milk and the mare's milk will exhibit better firmness and consistency as well as greater values of the viscosity index than those made from mare's milk alone. It was also assumed that the share of goat and sheep milk in the produced kefirs would have a positive effect on their mechanical properties during 3-week storage.

The aim of this study was to conduct instrumental and sensory analyses of the texture profile for kefirs produced from mare's milk and its mixtures with goat and sheep milk.

\section{Materials and methods}

\section{Mare's milk and its mixtures}

The raw material for analyses was bulk milk collected from Polish Cold-blooded multiparous mares reared on an equine dairy farm in the Wielkopolska region (Western Poland). At the time of milk collection for analyses they were in their fourth month of lactation. Mares with foals spent most of the days on the pasture foraging.

Mixtures were prepared by adding bulk goat milk from morning and evening milkings (of the Polish White Improved goats) and milk from sheep with an over $90 \%$ share of East-Friesian sheep in their genotype (Gut et al., 2008). Bulk milk from each of the above-mentioned species at $5 \mathrm{~L}$ per day was collected at the same time of the day for three successive days, collecting a total of $15 \mathrm{~L}$ milk from each species. After cooling down, the milk was transported and stored in accordance with the binding veterinary standards.

Ruminants, from which milk for analyses was collected, were fed with a mixture of concentrates and roughage (green lucerne forage and meadow hay) administered in the total mixed ration system (TMR). Farms, on which all these animal species were kept, were located within a distance of approx. $30 \mathrm{~km}$ in Western Poland.

The production of the mixture was started immediately after the collection and cooling of the last, third sample of bulk milk from all the three animal species. Raw whole mare's milk contained $15.1 \pm 0.5 \mathrm{~g} \cdot \mathrm{kg}^{-1}$ fat. For this reason the other types of milk were corrected to the same fat content by centrifugation, followed by double homogenisation $\left(1^{\circ}-15 \mathrm{MPa}, 2^{\circ}-4 \mathrm{MPa}\right)$. Next, a 1:1 mixture of mare's milk with goat milk and a 1:1 mixture of mare's milk with sheep milk were prepared. Such a proposed share in the mixture of each of the milks resulted from the previously conducted studies of the authors (Cais-Sokolińska et al., 2016).

\section{Production of kefir samples}

Pasteurised ( $90{ }^{\circ} \mathrm{C}$ for 2 min.) mare's milk and its mixtures were acidified using lactic acid-alcoholic fermentation with a share of mesophilic strains of lactic acid bacteria (LAB): Lactococcus lactis subsp. lactis, Lactococcus lactis subsp. cremoris, Lactococcus 
lactis subsp. lactis biovar diacetylactis, Leuconostoc mesenterroides subsp. cremoris, Lactobacillus plantarum, Lactobacillus casei as well as yeast Kluyveromyces fragilis (Kluyveromyces marxianus subsp. marxianus). The starter cultures were a commercial product, introduced in a lyophilized form at 30 u.a. to $100 \mathrm{~L}$ of milk and incubation was carried out at $22{ }^{\circ} \mathrm{C}$. The dose of the introduced cultures was selected so that the end point of the fermentation would provide a product with $\mathrm{pH}$ 4.5-4.4. The products were poured into PS (polystyrene) containers with a capacity for $150 \mathrm{~g}$ of the product, and were then cooled to $5 \pm 1{ }^{\circ} \mathrm{C}$. The products were tested $48 \mathrm{~h}$ after the end of the fermentation process ( 0 weeks) and after 3 -week storage at $5 \pm 1{ }^{\circ} \mathrm{C}$.

The process was run on a pilot plant scale with 9 samples for each type of product.

\section{Physicochemical analysis}

The basic chemical composition and $\mathrm{pH}$ were determined using standard methods (AOAC 1995; Cais-Sokolińska et al., 2015a). Total nitrogen content by Kjeldahl method was determined with the assistance of the Kjetec System 1026 apparatus of the Distilling Unit (Tecator Company, Örebro, Sweden). Nitrogen-casein was expressed as \% of total nitrogen ( $\mathrm{N} x$ 6.38). Casein concentration was calculated from the difference between the level of total protein (TP) and non-casein nitrogen (NCN). The level of whey proteins was determined from the difference between NCN and non-protein nitrogen (NPN) (AOAC, 2000; Amatayakul et al., 2006; Chever et al., 2014). The total number of bacteria (TBC) and somatic cell counts (SCC) were detected by the flow cytometric method on Bactocount IBC-m (Bentley Instruments, MN, USA), according to the ISO 21187 (2004) standard. A Bactocount apparatus was calibrated on the basis of the numbers of colonies, which were determined by reference method (counting the colonies of bacteria at $30{ }^{\circ} \mathrm{C}$ ), according to the ISO 4833 (2003) standard (Bentley Polska Sp. o. o.).

\section{Rheological and profile texture analyses}

Values of dynamic viscosity of unfermented milk were determined applying a method described by Anema et al. (2004). Absolute values of dynamic viscosity of samples before fermentation were recorded using a Hőppler KF10 viscosi- meter by RheoTec Messtechnik GmbH (Ottendorf, Germany). The time (s) was measured ( $\mathrm{t}$ ) for a ball to fall over a distance of $100 \mathrm{~mm}$ at an inclination angle of $70^{\circ}$ within a volume $\mathrm{v}=40 \mathrm{~cm}^{3}$. The angle constant for the measurement was $\mathrm{F}_{\mathrm{H}}=0.952(-)$. Balls used in the tests were made from an $\mathrm{Fe}-\mathrm{Ni}$ alloy with diameters $\varnothing_{\mathrm{k} 3}=15.552 \mathrm{~mm}$ and $\varnothing_{\mathrm{k} 4}=15.199 \mathrm{~mm}$ and mass $\mathrm{m}_{\mathrm{k} 3}=16.0627 \mathrm{~g}$ and $\mathrm{m}_{\mathrm{k} 4}=14.1797 \mathrm{~g}$, density $d_{k 3}=8.156 \mathrm{~g} \cdot \mathrm{cm}^{-3}$ and $d_{k 4}=7.713 \mathrm{~g} \cdot \mathrm{cm}^{-3}$ at the apparatus constants ascribed based on the certificate $\mathrm{K}_{3}=0.13543 \mathrm{mPa} \cdot \mathrm{cm}^{3} \cdot \mathrm{g}^{-1}$ and $\mathrm{K}_{4}=1.2268 \mathrm{mPa} \cdot \mathrm{cm}^{3} \cdot \mathrm{g}^{-1}$. On the basis of sample density $\left(d_{p}\right)$, established using an areometer by Areometr (Warszawa, Poland) at a fiducial temperature $\left(\mathrm{T}=20^{\circ} \mathrm{C}\right)$ within the range from 1015 to

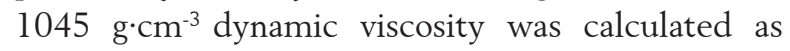
$\eta=t\left(d_{k}-d_{p}\right) \cdot K \cdot F(m P a \cdot s)$.

Firmness, consistency, cohesiveness and the viscosity index of fermented samples were determined using reverse extrusion in a TA-XT plus texture meter by Stable Micro Systems (Surrey, UK) (Pereira et al., 2003; Vargas et al., 2008). The $\mathrm{A} / \mathrm{BE}$ attachment with a compression disc $(\varnothing=35 \mathrm{~mm})$ was used. A sample was placed inside a cylinder with an internal diameter $\varnothing=50 \mathrm{~mm}$ (75\% filling). Measurement conditions were: a distance of $30 \mathrm{~mm}$, pre-test $1.0 \mathrm{~mm} \cdot \mathrm{s}^{-1}$ and post-test $10.0 \mathrm{~mm} \cdot \mathrm{s}^{-1}$. Samples for analyses were prepared according to Marshall and Rawson (1999) and Brennan and Tudorica (2008). Sample behaviour during compression and return movement of the disc was analysed (sample firmness - maximum positive force $\mathrm{F}^{+}$, consistency - space under the curve of force $F^{+}$in time $t_{1}: t_{2}$, cohesiveness - maximum negative force $\mathrm{F}^{-}$, viscosity index - space under the curve of force $F^{-}$in time $t_{2}: t_{3}$ ). Results were recorded in the Texture Exponent E32 version 4.0.9.0 software.

\section{Sensory analysis of the texture profile}

Sensory evaluation was conducted using the profiling method. Mouthfeel attributes reflecting the texture profile of tested samples were determined. Descriptors of the analyses together with their descriptions were as follows - Prickling - a tingling feeling on the tongue similar to a carbonated mineral water; Density - the thickness of samples in the mouth after the panelists have taken a bite; Creamy - velvet/soft feeling in the mouth (not fatty/oily); smoothness - the extent, to which 
samples ave an even consistency (absence of any granules); Mouth-coating - sensation of a thin film coating the oral cavity; Fatty sensation - fatty feeling on oral tissues perceived after swallowing (Wróblews$\mathrm{ka}$ et al., 2009). The evaluation panel comprised 8 individuals ( 3 males, 5 females, aged 23-51 years), adequately trained and prepared for examinations. They evaluated the intensity of each descriptor in a scale of 1 to 10 points, where 1 denotes "imperceptible" and 10 - "highly perceptible". Analyses were conducted in a sensory examination laboratory under controlled temperature and lighting conditions (ISO 8589, 1998). Sample volume was $40 \mathrm{~mL}$ and temperature $7-8{ }^{\circ} \mathrm{C}$ (Gomes et al., 2013).

\section{Statistical analysis}

A critical level of significance at $p=0.05$ was used throughout this study. Two-way ANOVA, Bonferroni test and Tukey's test were used to test the significance of differences. Statistical calculations were carried out using the STATISTICA, version 10 data analysis software (StatSoft, Inc. 2011).

\section{Results and discussion}

Chemical properties and composition of unfermented mare's milk and its mixtures

The mixture of sheep and goat milk used in the production process was of good hygienic quality. In both milk types TBC was max. $200 \times 10^{3} \cdot \mathrm{mL}^{-1}$. Also SCC values were high, in sheep milk amounting to $283.6 \times 10^{3}$ cells $\mathrm{mL}^{-1}$ and in goat milk to $462.5 \times 10^{3}$ cells $\mathrm{mL}^{-1}$. Mare's milk had
$18.2 \times 10^{3} \mathrm{TBC} \mathrm{mL}^{-1}$ and $23.4 \times 10^{3} \mathrm{SCC} \mathrm{mL}^{-1}$, thus confirming its high quality expressed in terms of its microbiological and cytological parameters. Results of hygienic quality evaluation for all the three milk types indicate appropriate milking and milk handling after milking, in this way confirming results recorded by other authors for high quality processed milk (Danków et al., 2003; Skrzypek et al., 2003; Cieślak et al., 2015).

Mare's milk and its mixtures used as the experimental material varied in terms of their rheological properties. Among unfermented samples the lowest viscosity (3.09 $\mathrm{mPa} \cdot \mathrm{s}$ ) was recorded for mare's milk. Statistically significant greater viscosity was found for a mixture of mare's milk with goat milk (4.36 $\mathrm{mPa} \cdot \mathrm{s}$ ) and a mixture with sheep milk (4.45 $\mathrm{mPa} \cdot \mathrm{s}$ ), which was probably connected with the content of proteins, mainly casein (Table 1). Jandal (1996) in goat and sheep milk reported the share of whey proteins in the total protein content at $15 \%$ and $13 \%$, respectively.

However, this value to a considerable degree is dependent on the animal breed, resulting in discrepancies between literature data. For example, Bornaz et al. (2010) reported the ratio of casein proteins to whey proteins in goat milk of 3.6, at the share of whey proteins amounting to almost $21 \%$. Ceballos et al. (2009) when determining the protein profile showed that in the total amount of protein in goat milk whey proteins account for $17.3 \%$, while casein proteins account for $82.7 \%$ (including $\alpha_{\mathrm{S} 1}$-casein at $18.92 \%, \alpha_{\mathrm{S} 2}$-casein at $8.52 \%$ and $\beta+\kappa$-casein at $55.26 \%$ ). The ratio of casein proteins to whey proteins in milk tested by those authors

Table 1. Basic chemical composition of unfermented mare's milk and its mixtures (mean \pm SD)

\begin{tabular}{|c|c|c|c|}
\hline \multirow{2}{*}{$\begin{array}{l}\text { Component } \\
\left(\mathrm{g} \cdot \mathrm{kg}^{-1}\right)\end{array}$} & \multicolumn{3}{|c|}{ Mare's milk and its mixtures $(1: 1)$} \\
\hline & mare & mare+goat & mare+sheep \\
\hline Protein $(\mathrm{N} \times 6.38)$ : & $23.9 \pm 0.2^{\mathrm{a}}$ & $26.1 \pm 0.1^{\mathrm{b}}$ & $29.5 \pm 0.2^{c}$ \\
\hline casein & $14.9 \pm 0.3^{\mathrm{a}}$ & $18.8 \pm 0.3^{\mathrm{a}}$ & $20.6 \pm 0.2^{c}$ \\
\hline whey protein & $9.0 \pm 0.5^{b}$ & $7.3 \pm 0.1^{\mathrm{a}}$ & $8.9 \pm 0.5^{b}$ \\
\hline $\mathrm{C}: \mathrm{W}^{*}$ & 1.7 & 2.6 & 2.3 \\
\hline $\mathrm{SNF}^{* *}$ & $84.0 \pm 0.3^{\mathrm{b}}$ & $80.7 \pm 0.6^{a}$ & $87.9 \pm 0.7^{c}$ \\
\hline
\end{tabular}

"C:WP - ratio of casein to whey protein

SNF - solids-not-fat

a-c different small letters with mean values in rows indicate statistically significant differences at $\mathrm{p}<0.05$ 
was 4.8. In turn, mare's milk is rich in whey proteins, accounting for $39 \%$ total protein content (Bornaz et al., 2010). Markiewicz-Kęszycka et al. (2013) studied the composition of milk from Polish Coldblooded mares and found that $\beta$-lactoglobulin $(29.2 \%)$ and $\alpha$-lactoalbumin (25.4\%) had the greatest share in whey proteins.

Casein proteins are present in milk as micelles forming a colloid solution. Micelles are composed of monomers of individual casein fractions bound with bridges formed by calcium, phosphate and citrate ions. On average $1 \mathrm{~cm}^{3}$ milk contains approx. $7 \cdot 10^{13}$ micelles and their diameter has a significant effect on the measure of internal friction, such as viscosity (Park, 2007). A study by Bornaz et al. (2010) showed that over $20 \%$ casein proteins in goat milk are from 125 to $150 \mathrm{~nm}$ in diameter. In turn, Park (2007) stated that casein proteins in goat milk have a diameter $\varnothing=260 \mathrm{~nm}$ and this value is much greater than in sheep milk $(\varnothing=193 \mathrm{~nm})$. Malacarne et al. (2002) reported that the diameter of casein protein micelles in mare's milk is $\varnothing=255 \mathrm{~nm}$. However, it needs to be stressed that the total amount of casein proteins in mare's milk is the smallest among the analysed milk types (Pegliarini et al., 1993).

Table 2. Parameters of texture of kefir from mare's milk and its mixtures during cold storage (mean \pm SD)

\begin{tabular}{cccc}
\hline \multirow{2}{*}{$\begin{array}{c}\text { Storage } \\
\text { time } \\
\text { (weeks) }\end{array}$} & mare & Kefir from milk \\
\cline { 2 - 4 } & \multicolumn{3}{c}{ Firmness $(\mathrm{g})$} \\
\hline 0 & $20 \pm 2^{\mathrm{aB}}$ & $174 \pm 15^{\mathrm{cA}}$ & $50 \pm 14^{\mathrm{bA}}$ \\
\hline 1 & $20 \pm 1^{\mathrm{aB}}$ & $168 \pm 12^{\mathrm{cA}}$ & $50 \pm 8^{\mathrm{bA}}$ \\
\hline 2 & $19 \pm 5^{\mathrm{aB}}$ & $168 \pm 7^{\mathrm{cA}}$ & $53 \pm 5^{\mathrm{bA}}$ \\
\hline 3 & $10 \pm 3^{\mathrm{aA}}$ & $162 \pm 21^{\mathrm{cA}}$ & $58 \pm 13^{\mathrm{bA}}$ \\
\hline & \multicolumn{3}{c}{ Cohesiveness $(\mathrm{g})$} \\
\hline 0 & $-306 \pm 25^{\mathrm{aA}}$ & $-280 \pm 3^{\mathrm{bA}}$ & $-270 \pm 8^{\mathrm{bA}}$ \\
\hline 1 & $-264 \pm 27^{\mathrm{aB}}$ & $-278 \pm 8^{\mathrm{bA}}$ & $-241 \pm 7^{\mathrm{bB}}$ \\
\hline 2 & $-265 \pm 14^{\mathrm{aB}}$ & $-141 \pm 11^{\mathrm{cB}}$ & $-243 \pm 12^{\mathrm{bB}}$ \\
\hline 3 & $-127 \pm 13^{\mathrm{bC}}$ & $-130 \pm 19^{\mathrm{bB}}$ & $-201 \pm 15^{\mathrm{aC}}$ \\
\hline
\end{tabular}

a-c; A-C different small letters with mean values in rows and capital letters with mean values in columns separately for firmness and cohesiveness indicate statistically significant differences at $\mathrm{p}<0.05$

\section{Texture profile}

Values of firmness, cohesiveness and consistency were calculated based on the curves plotted for measurement results recorded in tests for mechanical properties of mare's milk and its mixtures subjected to fermentation and further storage. Analysis of texture attributes of the samples showed that firmness of kefirs produced using mixtures of mare's milk was significantly greater than that of kefir from mare's milk alone (Table 2). At the same time, kefir from a mixture of mare's milk with goat milk was 3.5-fold firmer than that from the mixture with sheep milk $(\mathrm{P}<0.05)$.

Directly after production kefir from mare's milk was more cohesive (306 g) than kefirs made with an addition of goat milk (280 g) or sheep milk (270 g) (Table 2). However, after 3-week storage cohesiveness of kefir from mare's milk was identical as that of kefir produced from the mixture with goat milk and it was 2.5-fold lower than after production. Cohesiveness of kefir containing sheep milk storage decreased by one quarter after 3 weeks of storage.

Viscosity indexes were to a considerable degree dependent on the type of used milk (Fig. 1). Among analyzed samples of kefir from mare's milk and its mixtures statistically significant differences were observed for viscosity indexes ranging from 81 to $438 \mathrm{~g} \cdot \mathrm{s}$. Irrespective of testing time of the analyzed samples, the greatest value of the

Figure 1. The effect of type of kefir from mare's milk and its mixtures on the significance of differences in viscosity index ( $|\mathrm{g} \cdot \mathrm{s}|$ )

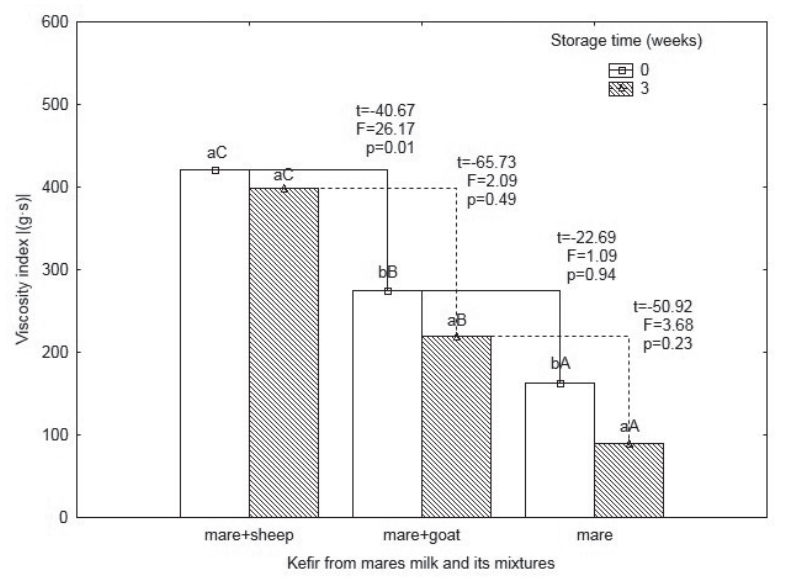

$\mathrm{t}$-value of the Bonferroni test, $\mathrm{F}$ - variance quotient, $\mathrm{p}$ - value of test probability

$\mathrm{a}-\mathrm{b}$; A-C different small letters for storage and capital letters for sample indicate statistically significant differences at $\mathrm{p}<0.05$ 
viscosity index was recorded for kefir produced from a mixture of mare's milk with sheep milk (409 g.s), while kefir made from mare's milk alone showed the lowest value (126 g.s). The observed difference in viscosity index for kefirs directly after production and after 3-week storage was not statistically significant, except for samples with different share of sheep milk in the mixture $(\mathrm{P}>0.05)$. Considering other tested samples, viscosity indexes in were significantly greater after a 3 -week storage than directly after their production, by $20 \%$ in kefir made with the addition of goat milk and by as much as $45 \%$ in kefir from mare's milk alone.

Such low viscosity of fermented beverages based on mare's milk in comparison to samples with a share of goat or sheep milk seems to originate from b lower contents of casein proteins in mare's milk and thus a lower ratio of casein proteins to whey proteins, as well as from a different proportion of the casein fraction and the size of casein micelles. Mare's milk is composed of identical amounts of $\beta$-casein and $\alpha_{s 1}$-casein, which is the dominant fraction of cow milk (Ochirkhuyag et al., 2000; Malacarne et al., 2002). The content of $\kappa$-casein in mare's milk is also lower than in cow milk (Egito et al., 2002). Casein micelles in mare's milk are larger and less porous than in cow milk (Buchheim et al., 1989). These differences significantly determine rheological properties of fermented milk.

Figure 2. The effect of type of kefir from mare's milk and its mixtures on the significance of differences in consistency $(\mathrm{g} \cdot \mathrm{s})$

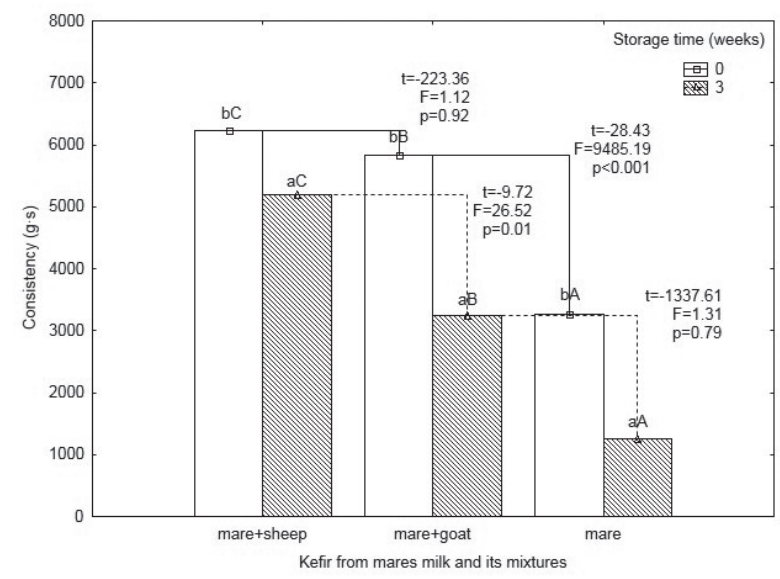

$\mathrm{t}$-value of the Bonferroni test, $\mathrm{F}$ - variance quotient, $\mathrm{p}$ - value of test probability

$\mathrm{a}-\mathrm{b}$; A-C different small letters for storage and capital letters for sample indicate statistically significant differences at $\mathrm{p}<0.05$
Upon the completion of the fermentation process the lowest value of the parameter describing consistency was recorded in kefir from mare's milk (3258 g.s), while it was highest in the product with the addition of sheep milk (6223 g.s.) (Fig 2). As a result of storage the value of consistency in each sample decreased significantly. Differences in consistency of the produced samples increased after 3 weeks. Consistency of kefir made from a mixture of mare's milk with sheep milk was 1.6-fold greater than that of kefir produced from a mixture of mare's milk with goat milk and as much as 4.1 -fold greater that the consistency of kefir from pure mare's milk.

The low value of consistency in kefir from mare's milk and its mixture with goat milk in comparison to sheep milk could have resulted from the low contents of casein proteins, particularly the $\alpha_{\mathrm{s} 1}$-casein fraction. In goat milk $\alpha_{\mathrm{s} 1}$-casein accounts only $18.9 \%$ of the total casein proteins. In mare's milk the share of this fraction is greater, amounting to $46.7 \%$, but total casein protein content is slightly over $10 \mathrm{~g} \cdot \mathrm{kg}^{-1}$. Consequently, curd of goat milk is frequently described in literature as soft, delicate and fine-grained. For comparison, in cow milk the share of the $\alpha_{\mathrm{s} 1}$-casein fraction is $48.5 \%$ total amount of casein proteins, being much greater than in other milk types and amounting to $25 \mathrm{~g} \cdot \mathrm{kg}^{-1}$ (Ceballos et al., 2009).

Figure 3. The importance of descriptors in sensory examination of texture in kefirs from mare's milk and its mixtures

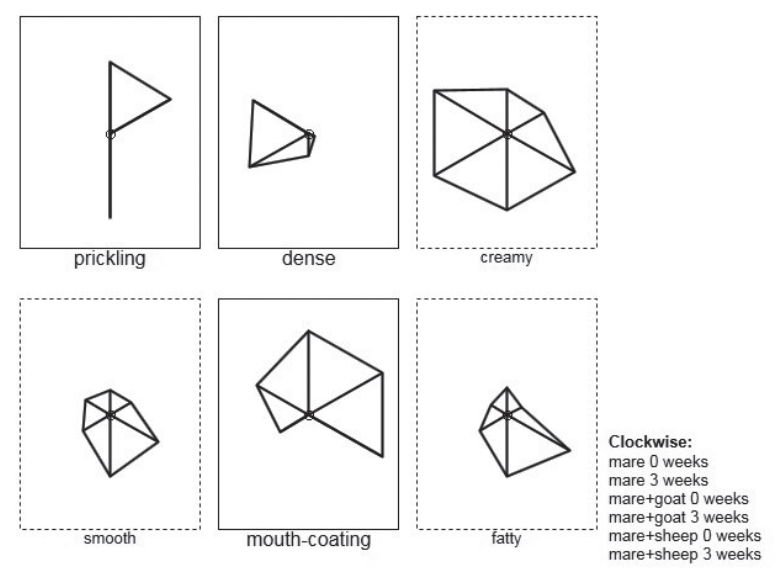

--- weak effect, — strong effect 
Texture in sensory examination - mouthfeel attributes

The evaluated descriptors were selected based on the exploration technique consisting in the presentation of recorded values in the form of multidimensional graphic objects (Fig. 3). This technique facilitated identification of interactive dependencies between samples depending on their type and storage time. No statistically significant difference $(\mathrm{P}>0.05)$ were found between kefirs when evaluating creamy, smooth and fatty perception. It was shown that the descriptions of prickling, dense and mouth-coating perception were those which differentiated the samples to the greatest extent. These dependencies were observed both after production and after 3-week storage. The prickling sensation, connected mainly with the presence of carbon dioxide, was most detectable in kefir from pure mare's milk (Table 3). The addition of goat milk and particularly sheep milk significantly decreased the prickling sensation $(\mathrm{P}<0.05)$. In kefirs produced from mixtures of mare's milk, the prickling perception decreased significantly with time, which was not observed in kefir from mare's milk alone. The dense sensation was did not change during sample storage and intensified with the use of milk from

Table 3. Sensory descriptors of kefir from mare's milk and its mixtures during cold storage (mean \pm SD)

\begin{tabular}{|c|c|c|c|}
\hline \multirow{2}{*}{$\begin{array}{c}\text { Storage } \\
\text { time } \\
\text { (weeks) }\end{array}$} & \multicolumn{3}{|c|}{ Kefir from milk } \\
\hline & mare & mare + goat & mare +sheep \\
\hline & \multicolumn{3}{|c|}{ prickling (scale 1-10) } \\
\hline 0 & $4.0 \pm 0.2^{\mathrm{cA}}$ & $2.1 \pm 0.3^{\mathrm{bA}}$ & $1.3 \pm 0.3^{\mathrm{aA}}$ \\
\hline \multirow[t]{2}{*}{3} & $4.1 \pm 0.2^{\mathrm{cA}}$ & $3.4 \pm 0.4^{\mathrm{bB}}$ & $2.1 \pm 0.2^{\mathrm{aB}}$ \\
\hline & \multicolumn{3}{|c|}{ dense (scale 1-10) } \\
\hline 0 & $1.4 \pm 0.5^{\mathrm{aA}}$ & $2.2 \pm 0.2^{\mathrm{bA}}$ & $5.2 \pm 0.4^{\mathrm{cA}}$ \\
\hline \multirow[t]{2}{*}{3} & $1.5 \pm 0.3^{\mathrm{aA}}$ & $2.6 \pm 0.2^{\mathrm{bA}}$ & $4.8 \pm 0.1^{\mathrm{cA}}$ \\
\hline & \multicolumn{3}{|c|}{ mouth-coating (scale 1-10) } \\
\hline 0 & $4.5 \pm 0.4^{\mathrm{bA}}$ & $3.5 \pm 0.3^{\mathrm{aB}}$ & $3.2 \pm 0.3^{\mathrm{aA}}$ \\
\hline 3 & $4.7 \pm 0.3^{\mathrm{bA}}$ & $2.3 \pm 0.3^{\mathrm{aA}}$ & $4.6 \pm 0.2^{\mathrm{bB}}$ \\
\hline
\end{tabular}

a-c; A-B different small letters with mean values in rows and capital letters with mean values in columns separately for firmness and cohesiveness indicate statistically significant differences at $\mathrm{p}<0.05$ ruminants. The dense perception of kefir produced from the mixture of mare's milk with sheep milk $\left(\mathrm{x}_{\Delta \tau}=5.0\right.$ points $)$ was almost 2 -fold greater than that of kefir from the mixture of mare's milk with goat milk ( $\mathrm{x}_{\Delta \tau}=2.4$ points). Assessing the mouth-coating of kefirs, sensory panel gave the highest scores to samples from pure mare's milk (irrespective of the sensory examination time $\mathrm{x}_{\Delta \tau}=4.6$ score) and to samples with an addition of sheep milk, but only after storage (4.6 points).

Mouth-coating of kefirs with addition of sheep milk was by $30 \%$ less intensive immediately after production than after 3 -week storage $(\mathrm{P}<0.05)$. Thus it may be stated that the use of milk from ruminants to produce kefir is the primary cause for changes in prickling, dense and mouth-coating sensations during storage. Primary differences were associated with the protein system and structure, as well as dispersion and size of fat globulins being different than those in mare's milk. In turn, secondary differences were connected with the dynamic of the fermentation process, and thus in the range of proteolysis and lipolysis as well as produced metabolites, e.g. exopolysaccharides. Differences between tested kefirs resulting from different chemical composition and physical properties of milk produced by different mammalian species were reflected in sensory evaluation. The three selected mouthfeel attributes may also be identifiers of produced kefirs in the course of further studies. Wróblewska et al. (2009) investigated certain attributes of kefir with $\mathrm{pH} 4.60$ produced from cow milk with $2 \%$ fat content, and described values of prickling, dense and mouth-coating perception. Those authors did not report any prickling sensation in the examined control samples. The dense sensation was 2.6 in a $0-10$ scale, while the mouth-coating sensation was assessed at 5.7 points. Storage time ( 2 weeks) had no significant effect on the detectability of prickling, dense and mouth-coating sensations in kefirs.

\section{Conclusions}

Viscosity of unfermented mare's milk may be significantly increased by its partial supplementation with goat or sheep milk. By applying identical conditions of lactic acid-alcoholic fermentation with mesophilic LAB as those for mare's milk kefirs 
based on mixtures of mare's milk with goat or sheep milk may be produced. Kefir produced from a mixture of mare's milk with goat or sheep milk has a different texture profile than that produced from pure mare's milk. The share of goat and sheep milk in kefirs caused their greater firmness, consistency and higher viscosity index values. Only cohesiveness of kefirs from mare's milk was greater than that of its mixtures. Storage of kefirs causes significant changes in cohesiveness and consistency describing their mechanical properties. An exception is found for firmness of kefirs from both mixtures and the viscosity index of kefir with sheep milk, which remained stable for 3 weeks. The descriptors: prickling, dense and mouth-coating perception, evaluated in sensory examination of kefirs produced from mare's milk and its mixtures to a considerable extent reflect their different texture profiles. No significant difference were found between kefirs from mare's milk and its mixture with goat and sheep milk when evaluating creamy, smooth and fatty perception.

\section{Acknowledgements}

The part of the study was supported by grant no. 2500/B/P01/2008/35 from the Polish Ministry of Science and Higher Education.

\section{Reološka, teksturalna i senzorska svojstva kefira proizvedenog od kobiljeg mlijeka $i$ njegovih mješavina s kozjim i ovčjim mlijekom}

\section{Sažetak}

Cilj ovog istraživanja bio je provesti mliječno kiselu i alkoholnu fermentaciju kobiljeg mlijeka i mješavine kobiljeg mlijeka s kozjim kao i ovčjim mlijekom pomoću mezofilnih bakterija mliječne kiseline te odrediti reološka (indeks viskoznosti i konzistenciju), teksturalna (čvrstoća i kohezivnost) i senzorska (osjet peckanja, zbijenosti i premaza u ustima) svojstva proizvedenih kefira. Rezultati analiza pokazali su kako kefir proizveden od mješavine kobiljeg mlijeka s kozjim kao i ovčjim mlijekom ima bolju čvrstoću, konzistenciju i veći indeks viskoznosti $\mathrm{u}$ odnosu na kefir proizveden isključivo od kobiljeg mlijeka. Pohrana kefira u trajanju od 3 tjedna na temperaturi od $5 \pm 1{ }^{\circ} \mathrm{C}$ utjecala je na promjenu svih određivanih svojstava proizvoda. Izuzetak je svojstvo čvrstoće kefira proizvedenog od obje mješavine mlijeka te indeks viskoznosti kefira proizvedenog od mješavine kobiljeg i ovčjeg mlijeka, koji su ostali stabilni tijekom pohrane.

\section{Ključne riječi: kobilje mlijeko, kozje mlijeko, ovčje mlijeko, kefir, tekstura}

\section{References}

1. Amatayakul, T., Halmos, A.L., Sherkat, F., Shah, N.P. (2006): Physical characteristics of yoghurts made using exopolysaccharide producing starter cultures and varying casein to whey protein ratios, International Dairy Journal 16, 40-51. doi: 10.1016/j.idairyj.2005.01.004

2. Anema, S.G., Lowe, E.K., Li, Y. (2004): Effect of $\mathrm{pH}$ on the viscosity of heated reconstituted skim milk, International Dairy Journal 14, 541-548. doi: 10.1016/j.idairyj.2003.10.007

3. AOAC. (1995): Official methods of analysis, 2, (16 $6^{\text {th }}$ ed.), USA. Association of Official Analytical Chemists, Food Composition, Additive, Natural Contaminants.

4. AOAC. (2000): Official Methods of Analysis. Casein nitrogen content of milk. 998.06. AOAC International, Chapter 33, 52.

5. Arora, S.A., Patel, A.A., Chauhan, O.P. (2015): Trends in milk and milk products fortification with dietary fibers, American Journal of Advanced Food Science and Technology 3, 14-27. doi: 10.7726/ajafst.2015.1002

6. Bornaz, S., Guizani, N., Sammari, J., Allouch, W., Sahli, A., Attia, H. (2010): Physicochemical properties of fermented Arabian mares` milk, International Dairy Journal 20, 500-505. doi: 10.1016/j.idairyj.2010.02.001

7. Brennan, C.S., Tudorica, C.M. (2008): Carbohydrate-based fat replacers in the modification of the rheological, textural and sensory quality of yoghurt: comparative study of the utilisation of barley beta-glucan, guar gum and inulin, International Journal of Food Science and Technology 43, 824-833. doi: 10.1111/j.1365-2621.2007.01522.x

8. Buchheim, W., Lund, S., Scholtissek, J. (1989): Verleichende Untersuchungen zur Struktur und grosse von Caseinmicellen in der Milk verschidener Species, Kieler Milchwirtschaftliche Forschungsberichte 41, 253-265.

9. Cabiddu, A., Carta, G., Molle, G., Decandia, M., Addis, M., Piredda, G., Delogu, A., Pirisi, A., Lai, V., Cera, V., Taras, L., Lallai, C., Banni, S. (2005): Relationship between feeding regimen and content of conjugated linoleic acid in sheep milk and cheese, Options Méditerranéennnes $67,171-175$. 
10. Cagno, R., Tamborrino, A., Gallo, G., Leone, C., De Angelis, M., Faccia, M., Amirate, P., Gobetti, M. (2004): Uses of mare's milk in manufacture of fermented milks, International Dairy Journal 14, 767-775. doi: 10.1016/j.idairyj.2004.02.005

11. Cais-Sokolińska, D., Wójtowski, J., Pikul, J., Danków, R., Majcher, M., Teichert, J., Bagnicka, E. (2015a): Formation of volatile compounds in kefir made of goat and sheep milk with high polyunsaturated fatty acids content, Journal of Dairy Science 98, 6692-6705. doi: 10.3168/jds.2015-9441

12. Cais-Sokolińska, D., Pikul, J., Wójtowski, J., Danków, R., Teichert, J., Czyżak-Runowska, G., Bagnicka, E. (2015b): Evaluation of quality of kefir from milk obtained from goats supplemented with a diet rich in bioactive compounds, Journal of Science of Food and Agriculture 95 (6), 1343-1349. doi: $10.1002 /$ jsfa.6828

13. Cais-Sokolińska, D., Wójtowski, J., Pikul J. (2016): Lactose hydrolysis and lactase activity in fermented mixtures containing mare's, cow's, sheep's and goat's milk. International Journal of Food Science and Technology. doi: $10.1111 /$ ijfs.13202

14. Cieślak, J., Maćkowski, M., Czyżak-Runowska, G., Puppel, K., Kuczyńska, B., Wójtowski, J., Pawlak, P. (2015): Screening for the most suitable reference genes for gene expression studies in equine milk somatic cells, PLoS ONE 10, 10(10):e0139688. doi: 10.1371/journal.pone.0139688

15. Ceballos, L.S., Morales, E.R., Adarve, G.T., Castro, J.D., Martinez, L.P., Sanz-Sampelayo, M.R. (2009): Composition of goat and cow milk produced under similar conditions and analyzed by identical methodology, Journal of Food Composition and Analysis 22, 322-329. doi: 10.1016/j.jfca.2008.10.020

16. Chever, S., Guyomarch, F., Beaucher, E., Famelart, M.H. (2014): High-protein fat-free acid milk gels: Control of protein composition and heat treatment, International Dairy Journal 37, 95-103. doi: 10.1016/j.idairyj.2014.02.011

17. Danków, R., Cais-Sokolińska, D., Pikul, J., Wójtowski, J. (2003): Cytological quality of goat's milk, Weterinary Medicine Science and Practice 59, 77-80.

18. Decandia, M., Cabiddu, A., Molle, G., Branca, A., Epifani, G., Pintus, S., Tavera, F., Piredda, G., Pinna, G., Addis, M. (2007): Effect of different feeding systems on fatty acid composition and volatile compound content in goat milk, Options Méditerranéennnes 74, 129-134.

19. Egito, A.S., Miclo, L., Lopez C., Adam, A., Girardet, J.M., Gaillard, J.L. (2002): Separation and characterization of mares milk $\alpha_{\mathrm{S1}}{ }^{-}, \beta-, \kappa$ caseins, $\gamma$-casein-like, and proteose-peptone component 5-like peptides, Journal of Dairy Science 85, 697-706. doi: 10.3168/jds.S0022-0302(02)74126-X
20. Gomes, J.J.L., Duarte, A.M., Batista, A.S.M., de Figueiredo, R.M.F., de Sousa, E.P., de Souza, E.L., de Cássia, R., Ramos, Queiroga, R. (2013): Physicochemical and sensory properties of fermented dairy beverages made with goat's milk, cow's milk and a mixture of the two milks, Lebensmittel-Wissenschaft und Technologie 54, 18-24. doi: 10.1016/j.lwt.2013.04.022

21. Gut A., Wójtowski J., Stanisz M., Ślósarz P. (2008): Dairy performance of new Polish milk sheep, Annals of Animal Science 8, 411-415.

22. ISO 8589 (1998): Sensory analysis - general guidance for the design of test rooms.

23. ISO 4833 (2003): Microbiology of food and animal feeding stuffs - Horizontal method for the enumeration of microorganisms - Colony-count technique at 30 degrees $\mathrm{C}$.

24. ISO 21187 (2004): Milk-Quantitative determination of bacteriological quality - Guidance for establishing and verifying a conversion relationship between routine method results and anchor method results.

25. Jandal, J.M. (1996): Comparative aspects of goat and sheep milk, Small Ruminant Research 22, 177-185. doi: 10.1016/S0921-4488(96)00880-2

26. Kücűkcetin,A., Yaygin,H.,Hinrichs, J., Kulozik, U. (2003): Adaptation of bovine milk towards mares' milk composition by means of membrane technology for koumiss manufacture, International Dairy Journal 13, 945-951. doi: 10.1016/S0958-6946(03)00143-2

27. Malacarne, M., Martuzzi, F., Summer, A., Mariani, P. (2002): Protein and fat composition of mare's milk: some nutritional remarks with reference to human and cow's milk, International Dairy Journal 12, 869-877. doi: 10.1016/S0958-6946(02)00120-6

28. Markiewicz-Kęszycka, M., Wójtowski, J., Kuczyńska, B., Puppel, K., Czyżak-Runowska, G., Bagnicka, E., Strzałkowska, N., Jóźwik, A., Krzyżewski, J. (2013): Chemical composition and whey protein fraction of late lactation mare milk, International Dairy Journal 31, 62-64. doi: 10.1016/j.idairyj.2013.02.006

29. Marshall, V.M., Rawson, H.L. (1999): Effects of exopolysaccharide-producing strains of thermophilic lactic acid bacteria on the texture of stirred yoghurt, International Journal of Food Science and Technology 34, 137-143. doi: 10.1046/j.1365-2621.1999.00245.x

30. Nassal, J., Rembalski, C. (1980): Hygienische Forderungen bei der Produktion von Stutenmilk und kumys, Archiv für Lebensmittelhygiene 31, 209-212.

31. Ochirkhuyag, B., Chobert, J.M., Dalgalarrondo, M., Haertle, T. (2000): Characterization of mare caseins. Identification of $\alpha_{\mathrm{S1}}$ - and $\alpha_{\mathrm{S} 2}$-caseins, Lait 80, 223-235. doi: 10.1051/lait:2000121

32. Park, Y.W. (2007): Rheological characteristics of goat and sheep milk, Small Ruminant Research 68, 73-87. doi: 10.1016/j.smallrumres.2006.09.015 
33. Pegliarini, E., Solaroli, G., Peri, C. (1993): Chemical and physical characteristics of mare's milk, Italian Journal of Food Science 5, 323-332.

34. Pereira, R.B., Singh, H., Munro, P.A., Luckman, M.S. (2003): Sensory and instrumental textural characteristics of acid milk gels, International Dairy Journal 13, 655-667. doi: 10.1016/S0958-6946(03)00071-2

35. Pikul, J., Wójtowski, J., Danków, R., Kuczyńska, B., Łojek, J. (2008): Fat content and fatty acids profile of colostrum and milk of primitive Konik horses (Equus caballus gmelini Ant.) during six months of lactation, Journal of Dairy Research 75, 302-309. doi: 10.1017/S0022029908003336

36. Sandoval-Castilla, O., Lobato-Calleros, C., AguirreMandujano, E., Vernon-Carter, E.J. (2004): Microstructure and texture of yogurt as influenced by fat replacers, International Dairy Journal 14, 151-157. doi: 10.1016/S0958-6946(03)00166-3

37. Shihata, A., Shah, N.P. (2002): Influence of addition of proteolytic strains of Lactobacillus delbrueckii subsp. bulgaricus to commercial ABT starter cultures on texture of yoghurt, exopolysaccharide production and survival of bacteria, International Dairy Journal 12, 765-771. doi: 10.1016/S0958-6946(02)00071-7

38. Sieber, R., Collomb, M., Aeschlimann, A., Jelen, P., Eyer, H. (2004): Impact of microbial cultures on conjugated linoleic acid in dairy products - a review, International Dairy Journal 14, 1-15. doi: 10.1016/S0958-6946(03)00151-1

39. Singh, P., Wani, A.A., Karim, A.A., Langowski H.C. (2012): The use of carbon dioxide in the processing and packaging of milk and dairy products: A review, International Journal of Dairy Technology 65, 161-177. doi: 10.1111/j.1471-0307.2011.00744.x
40. Skrzypek, R., Wójtowski, J., Fahr, R-D. (2003): Hygienic quality of cow bulk tank milk depending on the method of udder preparation for milking, Archiv für Tierzucht 46, 405-411.

41. Stelios, K., Emmanuel, A. (2004): Characteristics of set type yoghurt made from caprine or ovine milk and mixtures of the two, International Journal of Food Science and Technology 39, 319-324. doi: 10.1111/j.1365-2621.2004.00788.x

42. Uysal, H., Kilic, S., Kavas, G., Akbulut, N., Kesenkas, H. (2003): Some properties of yoghurt made from caprine milk and bovine-caprine milk mixtures fortified by ultrafiltration or the addition of skim milk powder, International Journal of Dairy Technology 56, 177-181. doi: 10.1046/j.1471-0307.2003.00101.x

43. Vargas, M., Chafer, M., Albors, A., Chiralt, A., GonzalezMartinez, C. (2008): Physicochemical and sensory characteristics of yoghurt produced from mixtures of cows' and goats' milk, International Dairy Journal 18, 1146-1152. doi: 10.1016/j.idairyj.2008.06.007

44. Wójtowski, J., Danków, R., Skrzypek, R., Fahr, R.D. (2003): The fatty acid profile in kefirs from sheep, goat and cow milk, Milchwissenschaft 58, 633-636.

45. Wróblewska, B., Kołakowski, P., Pawlikowska, K., Troszyńska, A., Kaliszewska, A. (2009): Influence of the addition of transglutaminase on the immunoreactivity of milk proteins and sensory quality of kefir, Food Hydrocolloids 23, 2434-2445. doi: 10.1016/j.foodhyd.2009.06.023 